Regular Article

pISSN: 2288-9744, eISSN: 2288-9752

Journal of Forest and Environmental Science

Vol. 30, No. 2, pp. 179-188, May, 2014

http://dx.doi.org/10.7747/JFS.2014.30.2.179

\title{
Shifting Cultivation Effects on Soil Environment in Upland Watershed of Bangladesh
}

\author{
S.M. Sirajul Haque, Sanatan Das Gupta and Sohag Miah \\ Institute of Forestry and Environmental Sciences, University of Chittagong, Chittagong 4331, Bangladesh
}

\begin{abstract}
This research reports the effects of shifting cultivation on soil environment collecting samples from $0-5 \mathrm{~cm}$ soil depth from five locations viz. at Burburichhara, Maichchari, Longadu, Sukurchhari and Muralipara in Rangamati district of Chittagong Hill Tracts (CHTs). Soil analyses showed that fungal and bacterial population, microbial respiration and active microbial biomass, maximum water holding capacity, conductivity and moisture contents were significantly (at least $\mathrm{p} \leq 0.05$ ) lower in shifting cultivated soil compared to adjacent mixed tree plantations at all the sites. On an average in soils of 5 different shifting cultivated lands fungal population was $1.33 \times 10^{5} \mathrm{CFU} / \mathrm{g}$ dry soil and bacterial population $1.80 \times 10^{7} \mathrm{CFU} / \mathrm{g}$ dry soil and in mixed plantations fungal population was $1.70 \times 10^{5}$ and bacterial population $2.51 \times 10^{7} \mathrm{CFU} / \mathrm{g}$ dry soil. Organic matter and exchangeable $\mathrm{Ca}$ and $\mathrm{Mg}$ contents were significantly (at least $\mathrm{p} \leq 0.05$ ) lower and bulk density significantly (at least $\mathrm{p} \leq 0.05$ ) higher in shifting cultivated land in most of the locations compared to adjacent mixed tree plantations. Ratios of microbial respiration and organic carbon as well as active microbial biomass and organic carbon were distinctly lower and $\mathrm{pH}$ higher at 3 locations in shifting cultivated soils compared to mixed plantations. Findings of various soil properties, therefore, suggest that shifting cultivation has deteriorating effects on soil environment.
\end{abstract}

Key Words: Shifting cultivation, Soil biological properties, Chittagong Hill Tracts, soil physico-chemical properties, soil environment

\section{Introduction}

Shifting cultivation mostly prevalent in tropical countries of the world and affected area is more in Asia than any other continents. In Asia $55,000 \mathrm{~km}^{2}$ of the forest is cleared every year with a short rotation cycle of 3-10 years through this age old cultivation system (Seubert 1975). Clearing of closed-forest through shifting cultivation is $70 \%$ in Africa, $50 \%$ in Asia and 35\% in America (Sandra and Lori 1988; Sandra 1984). This cultivation system is practiced in India, Sri lanka, Malaysia, Indonesia, Thailand, Philippine, Colombia, Latin America, Madagascar and Brazil after clearing of forests with short rotation of 3 to 15 years (Andreas et al. 2007; Philon 1998; Becker 1995; Nicholas 1984). In Bangladesh major portion constituting $10.97 \%$ of upland watershed falls in Chittagong and Chittagong Hill Tracts (CHTs). Shifting cultivation is the primary occupation and major economic activities of the indigenous people living in CHTs. In this hill tract on $13180-\mathrm{km}^{2}$ land, thus population increased to 1.5 million altogether in 2009 (Wikipedia 2009) from 61957 indigenous and 1097 non-indigenous people in 1872 (Suhrawardy 1995). It was found that the number of families of shifting cultivators over time increased rapidly from 2163 in 1964 to 35000 in 2002

Received: June 14, 2012. Revised: November 26, 2013. Accepted: November 27, 2013.

Corresponding author: S.M. Sirajul Haque

Institute of Forestry and Environmental Sciences, University of Chittagong, Chittagong 4331, Bangladesh

Tel: 8801712239814, Fax: 88031-726310, E-mail: sms_haque@yahoo.com 
in CHTs (Tripura and Harun 2003). In this region, about $200-\mathrm{km}^{2}$ areas of various categories of forest lands are now being cultivated every year in this system (Tripura and Harun 2003). Now, this cultivation system has become unsustainable because of reducing its cultivation cycle to 2-3 years due to increase in number of shifting cultivators and also due to settlement of people from densely populated plain land to this mountainous region. Thus, present production of crops from existing shifting cultivation of this area can hardly sustain for about 3-4 months due to very short rotation cycle and loss of top fertile soil. Shifting cultivation destructs forest vegetation as a whole and causes denudation of forest land, oxidizes organic matter and destroys microorganism and earthworm and silting stream channel (Sommer et al. 2004; Gupta 2000; Dodds et al. 1996; Dthar and Mishra 1987). Miah et al. (2010) reported shifting cultivation effects on soil fungi and bacteria population at two locations of Banderban and Rangamati districts of CHTs. This research, therefore, aimed to determine effects of shifting cultivation on over all soil environments.

\section{Materials and Methods}

Due to repeated shifting cultivation as well as deforestation process in CHTs it was very hard to select a pair of site representing a shifting cultivated land and natural forest covered area or mature plantation area side by side to find out the effect of shifting cultivation on soil environment. Therefore, to select such a pair site a reconnaissance survey was conducted in approachable locations of Rangamati district to determine environmental change in soil due to shifting cultivation. Following described 5 pair sites (Fig. 1) were selected in the dry season for soil sampling in the district:

\section{Burburichhara shifting cultivated area with adjacent planted mixed forest}

This current year shifting cultivated area was located at Burburichhara in Barkal upazila of Rangamati district with the geographical position of $22^{\circ} 43^{\prime} 07.03^{\prime \prime} \mathrm{N}$ and $92^{\circ} 21^{\prime}$ $02.19^{\prime \prime} \mathrm{E}$. This was a hilly area having steep (125-55\%) slopes with an elevation of $364 \mathrm{~m}$ on the north-west aspect. Existed vegetation on the land consisted of paddy (Oryza sativa spp.) and turmeric (Curcuma longa) as shifting culti- vated crops, Gmelina arborea (gamar) and banana (Musa paradisiaca) seedlings and some grasses in patches. Adjacent planted mixed forest was on steep (25-55\%) high hill facing the north-western aspect at $22^{\circ} 43^{\prime} 06.99^{\prime \prime} \mathrm{N}$ and $92^{\circ} 21^{\prime} 01.50^{\prime \prime} \mathrm{E}$ geographical positions. Vegetation consisted of Albizia lebbeck (koroi), G. arborea, and teak (Tectona grandis) along with bamboo, sungrass (Imperata arundinancea), banana etc. Tree canopy coverage was $98 \%$ and

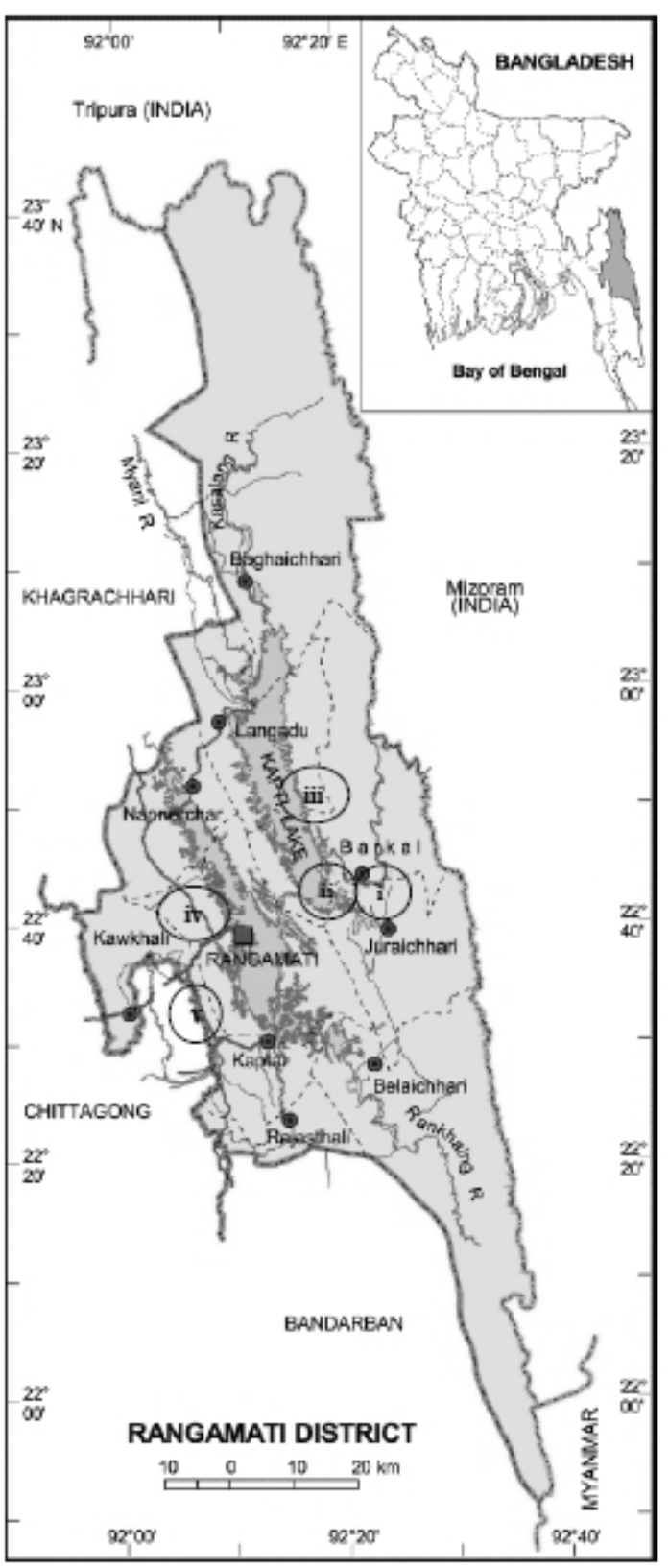

Fig. 1. Study site in upland watershed of Bangladesh. 
undergrowth coverage had $80 \%$ with $4 \mathrm{~cm}$ forest floor thickness.

Maijchhari shifting cultivated area with adjacent planted mixed forest

Maijchchari shifting cultivated area was located in Barkal upazila of Rangamati district at geographical $22^{\circ} 43^{\prime} 06.12^{\prime \prime} \mathrm{N}$ and $92^{\circ} 19^{\prime} 06.95^{\prime \prime} \mathrm{E}$ position. The area possessed $25-55 \%$ hill slope on south-western aspect having current year shifting cultivated land with crops of paddy, turmeric and banana. The adjacent planted mixed forest was on medium high hill with $25-55 \%$ slope at geographical $22^{\circ} 43^{\prime} 06.06^{\prime \prime} \mathrm{N}$ and $92^{\circ} 19^{\prime} 07.45^{\prime \prime} \mathrm{E}$ position on south-west aspect. Vegetation of this area were teak, Syzygium cumini (jam), Lagerstroemia speciosa (jarul), Barringtonia acutangula (hijal) and Laena coromandelica (vadi), which provided $70 \%$ canopy coverage with $30 \%$ undergrowth.

Longadu shifting cultivated area with adjacent planted mixed forest

This pair site was situated at Longadu upazila situated to the north-western part of Rangamati district at geographical position of $22^{\circ} 50^{\prime} 06.14^{\prime \prime} \mathrm{N}$ and $92^{\circ} 17^{\prime} 04.17^{\prime \prime} \mathrm{E}$ on steep high hill facing south eastern aspect. This was a current year shifting cultivated land with crops of paddy, turmeric, $b a$ nana etc. with no undergrowth. Adjacent planted mixed forest of teak and G. arborea was on steep (25-55\%) high hill slopes on south-eastern aspect at geographical position of $22^{\circ} 45^{\prime} 05.12^{\prime \prime} \mathrm{N}$ and $92^{\circ} 18^{\prime} 05.45^{\prime \prime} \mathrm{E}$. Tree canopy coverage on this hill was $70 \%$ with $40 \%$ undergrowth, mostly of herbs with very little or no litter on the forest floor.

Sukurchhari shifting cultivated area with adjacent planted mixed forest

This pair site was situated at Sukurchori, $7 \mathrm{~km}$ from Manikchari under Kutukchari Range under Un-classed State Forest Division on the way to Rangamati-ManikchariMohalchari-Khagrachari Road. This site was one year old shifting cultivated land on medium high hill on eastern aspect at geographical position of $22^{\circ} 40^{\prime} 05.22^{\prime \prime} \mathrm{N}$ and $092^{\circ} 07^{\prime}$ $02.35^{\prime \prime}$ E. Paddy residues of the previous year was still existed on the land with $75 \%$ grass vegetation and $15 \%$ ground coverage, mostly of Eupatorium odoratum (asamlata) of $80 \mathrm{~cm}$ in height. Adjacent to this shifting cultivated area mixed planted forest of litchi (Litchi chinensis), jackfruit (Artocarpus heterophyllus), teak, G. arborea and Syzygium cumini (jam) were present on upper part of the medium high hill at $22^{\circ} 41^{\prime}$ $05.45^{\prime \prime} \mathrm{N}$ and $092^{\circ} 06^{\prime} 02.42^{\prime \prime}$ E geographical positions. Tree canopy coverage of this plantation was $80 \%$ with full undergrowth coverage and $4 \mathrm{~cm}$ litter depth.

Muralipara shifting cultivated area with adjacent bushy forest

This site was 2 year old slashed and burnt area, situated at Mulari para on the way to Gagra, Kaptai Road, Phulgaji Forest Range under Jhum Control Division. In this shifting cultivated area vegetation was wild banana on eastern aspect of a medium high hill at geographical position of $22^{\circ} 34^{\prime} 09.42^{\prime \prime} \mathrm{N}$ and $092^{\circ} 06^{\prime} 02.29^{\prime \prime} \mathrm{E}$. Sun grasses was the only vegetation on this land that provided $15 \%$ coverage. Area adjacent to this shifting cultivated land was consisted of only one 25 year old jackfruit tree with bushy undergrowth on medium high hill top at geographical position of $22^{\circ} 33^{\prime} 05.82^{\prime \prime} \mathrm{N}$ and $092^{\circ} 07^{\prime} 06.22^{\prime \prime} \mathrm{E}$. This bushy vegetation covered a very small area.

\section{Soil sampling and analysis}

From each of the above mentioned 5 locations, 5 replicated soil samples were collected from a depth of $0-5 \mathrm{~cm}$ from each land use, mixed thoroughly to give a composite sample and brought to the laboratory in labeled poly bag sterilized with $95 \%$ ethyle alcohol. In the laboratory samples were divided into two sub-soil samples: one used for determination of physical and chemical properties and the other kept in incubator at $4^{\circ} \mathrm{C}$ temperature for determining biological properties. In both the cases, 3 sub-samples were taken from each composite sample for determination of various parameters of soil and result expressed for each parameter based on oven dry basis.

\section{Determination of physico-chemical properties}

Moisture content was determined drying the soil in an oven at $105^{\circ} \mathrm{C}$ for 8 hours (Huq and Alam 2005). Soil bulk density was determined from core samples (Blake 1965). Moist soil $\mathrm{pH}$ was determined by TOA $\mathrm{pH}$ meter in triplicate at 1:2 soil-water ratios. Soil organic carbon and organic matter were determined by loss on ignition method (Ball 1964) and total nitrogen by micro-Kjeldahl method (Jackson 1973). Electric conductivity was measured using a digital conductivity meter (TOA, Japan). Available phosphorus was extracted with Bray and Kurtz No.2 extractant and measured by $\mathrm{SnCl} 2$ reduced molybdophosphoric blue 
color method using spectrophotometer (Jackson 1973). Available calcium and magnesium was determined according to Petersen (2002).

\section{Determination of biological properties}

\section{Fungi}

Potato dextrose agar (PDA) media was used for culturing fungi. After primary washing of all the glass wares with water used in microbial culture were ringed with $95 \%$ ethyl alcohol and wrapped with brown paper. The sterile media of PDA kept in conical flask prepared previously after tight cotton plucking was also wrapped with brown paper. All the materials in wrapped condition were then placed carefully in an autoclave and sterilized at $121^{\circ} \mathrm{C}$ for 15 minutes to free from undesired microorganisms. Exactly $1 \mathrm{~g}$ sieved soil, passed through $2 \mathrm{~mm}$ mesh size, was dispersed in 99 $\mathrm{mL}$ sterile water in a conical flask to produce $10^{-2}$ dilution, from which $1 \mathrm{~mL}$ suspension taken out using sterilized pipette and mixed thoroughly adding $99 \mathrm{~mL}$ sterile water to another conical flask to give $10^{-4}$ dilution. In this way dilutions were made up to $10^{-5}$, and dilutions of $10^{-3}, 10^{-4}$ and $10^{-5}$ were used for culturing and isolation of fungi. Each of the conical flasks with different dilutions was then covered with a rubber stopper. Three replicated soil samples were analyzed for each depth and land use for making such dilutions. Laminar flow bench was first cleaned with absolute alcohol using cotton and allowed to pass ultra violate ray until fluorescent light lit on. All the sterilized glassware and PDA media in conical flask were then transferred to the running lamina flow bench unwrapping carefully to avoid any contamination. About $15 \mathrm{~mL}$ of sterilized PDA media from conical flask was poured evenly throughout the Petri-dish and thus 18 different replicated cultures prepared from PDA media. Exactly $0.1 \mathrm{~mL}$ streptomycin sulfate $\left(0.25 \mathrm{mg} \mathrm{mL}^{-1}\right)$ solution was added and spread to Petri-dish for inhibiting any bacterial growth and allowed to solidify (Miah et al. 2010).

For isolation, $1 \mathrm{~mL}$ soil suspension was pipette out from each of $10^{-2}$ and $10^{-4}$ dilutions to the test tubes, and $9 \mathrm{~mL}$ sterile distilled water added to get $10^{-3}$ and $10^{-5}$ dilutions, respectively. From each of the test tubes, $1 \mathrm{ml}$ soil suspension was then pipette out and spread over the solidified media in Petri-dishes. From each of the test tubes, $1 \mathrm{ml}$ soil suspension was then pipette out and spread over the solidified media in Petri-dishes. After 72 hours incubation all Petri-dishes were examined. Petri-dishes which had $>300$ or $<30$ colonies on the plates were discarded (Clark 1965). Colonies of diameter greater than $2 \mathrm{~cm}$ in any plate were also discarded. Total number of colonies on each of the acceptable plates were counted using colony counter and the result expressed as Colony Forming Unit (cfu) according to Clark (1965).

\section{Bacteria}

For culturing bacteria, nutrient agar (NA) media was used and dilutions made up to $10^{-9}$. Dilutions $10^{-7}, 10^{-8}$ and $10^{-9}$ were used for bacterial culture. All the procedures described for fungi above were applied for the culture of bacteria. However, following exceptions were for bacterial culture. Each of the dilutions in conical flasks was shaken vigorously for 10 minutes. Nystate solution $(0.005 \mathrm{mg}$ $\mathrm{mL}^{-1}$ ) was used as antifungal for the culture (Miah et al. 2010). After 24 hours incubation all Petri-dishes were examined.

Basal respiration in soil was estimated according to Dubey and Maheswari (1999). According to this method, $100 \mathrm{~g}$ moist soil was taken into a sterile $500 \mathrm{~mL}$ conical flask. Three test tubes, each containing freshly prepared 10 $\mathrm{mL}$ of $1 \mathrm{~N} \mathrm{NaOH}$, were placed inside to this conical flask. Each conical flask was then closed with a rubber stopper and sealed with wax. A set of blank experiment was also prepared to represent control. The conical flasks were then incubated at $30^{\circ} \mathrm{C}$ for 7 days, after which $1 \mathrm{~N} \mathrm{NaOH}$ solution was taken out from test tube, titrated against $\mathrm{N} / 10$ $\mathrm{HCl}$ in a conical flask adding 2 or 3 drops of phenolphthalein indicator. The end point of the reaction turned from pink to colorless. The basal respiration was calculated from the following relationship:

Basal respiration, $\mathrm{C}_{\text {Res. }}=\frac{\left(\mathrm{CO}_{2}-\mathrm{C}_{\text {soil }}-\mathrm{CO}_{2}-\mathrm{C}_{\text {air }}\right)}{\text { Incubation period }}$

where, $\mathrm{CO}_{2}-\mathrm{C}_{\text {soil }}$ represents evolution of $\mathrm{CO}_{2}$ from soil, and $\mathrm{CO}_{2}-\mathrm{C}_{\text {air }}$ represents atmospheric $\mathrm{CO}_{2}$ absorbed by $1 \mathrm{~N}$ $\mathrm{NaOH}$.

Active microbial biomass $\left(\mathrm{C}_{\mathrm{AMB}}\right)$ of soil was determined according to Van de Werf and Verstrate, (1987) glucose-amendment method, which also known as substrate induced respiratory assay. According to this method ap- 
proximately $0.2 \mathrm{~g}$ talc and $0.03 \mathrm{~g}$ glucose were grinded and thoroughly mixed with $20 \mathrm{~g}$ moist soil and taken into a 500 $\mathrm{mL}$ conical flask. Exactly $10 \mathrm{~mL}$ standardized $\mathrm{N} / 10$ $\mathrm{NaOH}$ was taken in each of the triplicate test tubes to trap $\mathrm{CO}_{2}$ and placed into conical flask. Conical flasks were then sealed with wax and incubated for 10 hours at room temperature $25^{\circ} \mathrm{C} \pm 1$. After incubation the amount of evolved $\mathrm{CO}_{2}$ was measured after titration the content against $\mathrm{N} / 10$ $\mathrm{HCl}$. The active microbial biomass $\left(\mathrm{C}_{\mathrm{AMB}}\right)$ was calculated from the following formula:

$\mathrm{C}_{\mathrm{AmB}}=\left(\mathrm{CO}_{2}-\right.$ Camend $-\mathrm{CO}_{2}-$ Cunamend $) A C$

where, $\mathrm{CO}_{2}-\mathrm{Camend}$ indicate evolution of $\mathrm{CO}_{2}$ from the glucose-talc amended soil, $\mathrm{CO}_{2}-\mathrm{Cunamend}$ indicate evolution of $\mathrm{CO}_{2}$ from soils only (un-amended), and $\mathrm{AC}$ is the coefficient (0.283) to convert $\mathrm{CO}_{2}-\mathrm{C}$ into CAMB (Van de Werf and Verstrate 1987).

Metabolic quotient $\left(\mathrm{C}_{\text {Res. }} \mathrm{C}_{\text {Org }}{ }^{-1}\right)$ was determined dividing basal respiration $\left(\mathrm{C}_{\text {Res. }}\right)$ by organic carbon. Again, metabolic quotient $\left(\mathrm{C}_{\mathrm{AMB}} \mathrm{C}_{\mathrm{Org}}{ }^{-1}\right)$ was determined dividing active microbial biomass $\left(\mathrm{C}_{\mathrm{AMB}}\right)$ by organic carbon $\left(\mathrm{C}_{\mathrm{Org}}\right)$ (Anderson and Domsch 1990). Significance difference between the means of shifting cultivation and mixed planted forest was determined by one way analysis with the triplicate data for each parameter using SPSS 16.0 package. Differences for the means between the shifting cultivation and mixed planted forest are shown in result at two different levels, for small difference at $\mathrm{p} \leq 0.05$ and large differ- ence at $\mathrm{p} \leq 0.001$.

\section{Results}

\section{Soil physico-chemical properties}

Moisture content, maximum water holding capacity and conductivity in soil were significantly (at least $\mathrm{p} \leq 0.05$ ) lower at all the 5 locations in Rangamati district of CHTs in shifting cultivated land compared to adjacent mixed planted forest (Table 1). Organic matter content significantly (at least $\mathrm{p} \leq 0.05$ ) lower and bulk density significantly (at least $\mathrm{p} \leq 0.05$ ) higher in shifting cultivated land at three locations viz: Burburichara, Maichhari and Langadu compared to mixed planted forest land and reverse true for other two locations viz. Sukurchari and Muralipara (Table 1, 2). Sukurchari was an orchard dominated planted forest and Muralipara contained only one jackfruit tree representing a poor forest cover. For this reasons at these two sites organic matter content was lower and bulk density became higher compared to shifting cultivated land. The relationship between organic matter and bulk density was inversely proportional at all the pair sites. At Burburichara moisture content, maximum water holding capacity, conductivity, bulk density and organic matter in shifting cultivated land were $12.60 \%, 27.21 \%, 113 \mu \mathrm{s} / \mathrm{cm}, 1.31 \mathrm{~g} \mathrm{~cm}^{-3}$ and $2.31 \%$, respectively, while their corresponding values in adjacent mixed planted forest were 18.60\%, 43.38\%, $201 \mu \mathrm{s} / \mathrm{cm}$, $1.23 \mathrm{~g} \mathrm{~cm}^{-3}$ and $2.75 \%$. Exchangeable $\mathrm{Ca}$ and $\mathrm{Mg}$ contents were significantly (at least $\mathrm{p} \leq 0.05$ ) higher in shifting culti-

Table 1. Soil physical properties in shifting cultivated and adjacent mixed planted forest lands of Rangmati hill district

\begin{tabular}{|c|c|c|c|}
\hline Land use & Moisture content (\%) & Maximum water holding capacity (\%) & Bulk density \\
\hline Burburichara shifting cultivated land & $12.60^{\mathrm{a} *}$ & $27.21 *$ & $1.31^{*}$ \\
\hline Adjacent mixed planted forest & $18.60 *$ & $43.38^{*}$ & $1.23^{*}$ \\
\hline Maichhari shifting cultivated land & $12.00 * * *$ & $28.06 * * *$ & $1.28^{*}$ \\
\hline Adjacent mixed planted forest & $25.24 * * *$ & $56.25 * * *$ & $1.12 *$ \\
\hline Langadu shifting cultivated land & $13.49 * * *$ & $32.28 *$ & $1.34 * * *$ \\
\hline Adjacent mixed planted forest & $31.22 * * *$ & $49.32 *$ & $1.19 * * *$ \\
\hline Shukurchari shifting cultivated land & $14.15 * * *$ & $33.89 * * *$ & $1.25 * * *$ \\
\hline Adjacent mixed planted forest & $34.64 * * *$ & $60.78 * * *$ & $1.46 * * *$ \\
\hline Muralipara shifting cultivated land & $3.49 *$ & $29.37^{*}$ & $1.37 * * *$ \\
\hline Adjacent bushy forest & $7.19^{*}$ & $46.80 *$ & $1.53 * * *$ \\
\hline
\end{tabular}

${ }^{a}$ Each value is the mean of 3 sub-soil samples of a composite from 5 spots in the field; * indicates significant difference between the means of shifting cultivated and adjacent mixed planted forest lands at $\mathrm{p} \leq 0.05$ and $* * *$ indicate at $\mathrm{p} \leq 0.001$. 
vated soil than the mixed planted forest in most of the locations. At Sukurchari exchangeable $\mathrm{Ca}$ and $\mathrm{Mg}$ were $5.62 \mathrm{meq} / 100 \mathrm{~g}$ soil and $1.64 \mathrm{meq} / 100 \mathrm{~g}$ soil in shifting cultivated land and their corresponding values were 1.61 $\mathrm{meq} / 100 \mathrm{~g}$ soil and $0.79 \mathrm{meq} / 100 \mathrm{~g}$ soil in mixed planted forest. Soil $\mathrm{pH}$ and available $\mathrm{P}$ did not show any definite trend between the lands (Table 2). For all the soils $\mathrm{N}$ determinations were not markedly differentiated.

\section{Soil biological properties}

Fungal and bacterial population, microbial respiration and active microbial biomass were significantly (at least $\mathrm{p} \leq$ $0.05)$ lower in shifting cultivated soil compared to adjacent mixed planted forest at all the five locations (Table 3). At Langadu fungal and bacterial population, microbial respiration and active microbial biomass in shifting cultivated land were $1.52 \times 10^{5} \mathrm{cfu} \cdot \mathrm{g}^{-1}$ dry soil, $1.85 \times 10^{7} \mathrm{cfu} \cdot \mathrm{g}^{-1}$ dry soil,

Table 2. Soil chemical properties in shifting cultivated and adjacent mixed planted forest lands in Rangmati hill district

\begin{tabular}{|c|c|c|c|c|c|c|c|c|}
\hline \multirow[t]{2}{*}{ Land use } & \multirow[t]{2}{*}{$\mathrm{pH}$} & \multirow{2}{*}{$\begin{array}{c}\text { Organic C } \\
(\%)\end{array}$} & \multirow{2}{*}{$\begin{array}{c}\text { Organic } \\
\text { matter }(\%)\end{array}$} & \multirow{2}{*}{$\begin{array}{l}\text { Conductivity } \\
(\mu \mathrm{s} / \mathrm{cm})\end{array}$} & \multirow{2}{*}{$\begin{array}{c}\text { Total N } \\
(\%)\end{array}$} & \multirow{2}{*}{$\begin{array}{c}\text { Available P } \\
\left(\mathrm{mg} \mathrm{kg}^{-1}\right)\end{array}$} & \multicolumn{2}{|c|}{$\begin{array}{l}\text { Available cations } \\
\text { (meq/ } 100 \mathrm{~g} \text { soil) }\end{array}$} \\
\hline & & & & & & & $\mathrm{Ca}++$ & $\mathrm{Mg}++$ \\
\hline Burburichara shifting cultivated land & $4.54^{\mathrm{a}}$ & $1.34 *$ & 2.31 & $113.00 * * *$ & $0.04 *$ & $7.8^{*}$ & $5.44^{* * * *}$ & $1.59 *$ \\
\hline Adjacent mixed planted forest & 4.22 & $1.60^{*}$ & 2.75 & $201.00 * * *$ & $0.09 *$ & $7.5^{*}$ & $2.50 * * *$ & $1.02 *$ \\
\hline Maichhari shifting cultivated land & $4.88^{*}$ & 1.69 & $2.31 *$ & $98.00 * * *$ & $0.06^{*}$ & $12.21 *$ & 4.37 & 1.09 \\
\hline Adjacent mixed planted forest & $4.28 *$ & 1.93 & $3.90 *$ & $326.00 * * *$ & $0.16^{*}$ & $10.6^{*}$ & 4.69 & 1.12 \\
\hline Langadu shifting cultivated land & 4.38 & $2.20 * *$ & $3.78 * * *$ & $308.80 * * *$ & $0.11^{*}$ & $4.50^{*}$ & $3.34 *$ & $1.25 *$ \\
\hline Adjacent mixed planted forest & 4.16 & $4.78 * *$ & $8.22 * * *$ & $625.00 * * *$ & $0.04 *$ & $6.38^{*}$ & $2.07 *$ & $1.11^{*}$ \\
\hline Shukurchari shifting cultivated land & $4.11^{*}$ & $1.42 * *$ & $2.45 * * *$ & $346.00 * * *$ & 0.07 & $6.53 * * *$ & $5.62 * * *$ & 1.64 \\
\hline Adjacent mixed planted forest & $4.60 *$ & $0.64 * *$ & $1.10 * * *$ & $519.00 * * *$ & 0.08 & $16.09 * * *$ & $1.61^{* * *}$ & 0.79 \\
\hline Muralipara shifting cultivated land & $4.73 *$ & $1.01^{*}$ & $1.73^{*}$ & $327.00 * * *$ & 0.07 & $2.30 * * *$ & $3.81 *$ & $2.30 *$ \\
\hline Adjacent bushy forest & $5.09 *$ & $0.93 *$ & $1.60^{*}$ & $482.00 * * *$ & 0.07 & $7.40 * * *$ & $4.46^{*}$ & $1.22 *$ \\
\hline
\end{tabular}

${ }^{a}$ Each value is the mean of 3 sub-soil samples of a composite from 5 spots in the field; * indicates significant difference between the means of each land use at $\mathrm{p} \leq 0.05$ and $* * *$ indicate at $\mathrm{p} \leq 0.001$.

Table 3. Fungal and bacterial population, microbial respiration and biomass of soil in shifting cultivated land adjacent mixed planted forest in Rangmati hill district

\begin{tabular}{|c|c|c|c|c|}
\hline Land use & $\begin{array}{c}\text { Fungal population } \\
\text { (CFU/g dry soil) }\end{array}$ & $\begin{array}{c}\text { Bacterial population } \\
\text { (CFU/g dry soil) }\end{array}$ & $\begin{array}{c}\text { Microbial respiration } \\
\left(\mathrm{CO}_{2}-\mathrm{C} / \mathrm{kg} / \text { day }\right)\end{array}$ & $\begin{array}{c}\text { Active microbial } \\
\text { biomass (mg C/kg soil) }\end{array}$ \\
\hline Burburichara shifting cultivated land & $1.32 \times 10^{5 \mathrm{a}}$ & $2.12 \times 10^{7} * *$ & $4.30 * * *$ & $51.47 * * *$ \\
\hline Adjacent mixed planted forest & $1.30 \times 10^{5}$ & $2.53 \times 10^{7} * *$ & $7.40 * * *$ & $72.47 * * *$ \\
\hline Maichhari shifting cultivated land & $1.40 \times 10^{5} * *$ & $2.35 \times 10^{7} * *$ & $5.28 * * *$ & $45.68 * *$ \\
\hline Adjacent mixedplanted forest & $1.85 \times 10^{5} * *$ & $2.84 \times 10^{7} * *$ & $7.51 * * *$ & $55.36^{* *}$ \\
\hline Langadu shifting cultivated land & $1.52 \times 10^{5 * * *}$ & $1.85 \times 10^{7} * * *$ & $4.19^{* *}$ & $67.48 * *$ \\
\hline Adjacent mixedplanted forest & $2.13 \times 10^{5} * * *$ & $2.81 \times 10^{7 * * *}$ & $4.51 * *$ & $76.44 * *$ \\
\hline Shukurchari shifting cultivated land & $1.38 \times 10^{5} * *$ & $1.58 \times 10^{7 * * * *}$ & $4.30^{* *}$ & $66.55 * * *$ \\
\hline Adjacent mixedplanted forest & $1.85 \times 10^{5 * *}$ & $2.79 \times 10^{7} * * *$ & $5.45 * *$ & $91.89 * * *$ \\
\hline Muralipara shifting cultivated land & $1.04 \times 10^{5 * *}$ & $1.05 \times 10^{7} * *$ & $3.57 * * *$ & $56.63 * *$ \\
\hline Adjacent bushy forest & $1.38 \times 10^{5} * *$ & $1.59 \times 10^{7} * *$ & $5.22 * * *$ & $62.31 * *$ \\
\hline Mean of shifting cultivated land & $1.33 \times 10^{5}$ & $1.80 \times 10^{7}$ & 4.33 & 57.56 \\
\hline Mean of mixed planted forest & $1.70 \times 10^{5}$ & $2.51 \times 10^{7}$ & 6.02 & 71.70 \\
\hline
\end{tabular}

${ }^{a}$ Each value is the mean of 3 sub-soil samples of a composite from 5 spots in the field; $* *$ indicates significant difference between the means of each land use at $\mathrm{p} \leq 0.01$ and $* * *$ indicate at $\mathrm{p} \leq 0.001$. 
$4.19 \mathrm{CO}_{2}-\mathrm{C} \mathrm{kg}^{-1} /$ day and $67.48 \mathrm{mg} \mathrm{C} / \mathrm{kg}$ soil, respectively, while in adjacent mixed planted forest their corresponding values had $2.13 \times 10^{5} \mathrm{cfu} \cdot \mathrm{g}^{-1}$ dry soil, $2.81 \times 10^{7} \mathrm{cfu} \cdot \mathrm{g}^{-1}$ dry soil, $4.51 \mathrm{CO}_{2}-\mathrm{C} / \mathrm{kg} /$ day and $76.44 \mathrm{mg} \mathrm{C} / \mathrm{kg}$ soil. On an average fungal and bacterial population, microbial respiration and active microbial biomass were $1.33 \times 10^{5} \mathrm{cfu} \cdot \mathrm{g}^{-1}$ dry soil, $1.80 \times 10^{7} \mathrm{cfu} \cdot \mathrm{g}^{-1}$ dry soil, $4.33 \mathrm{CO}_{2}-\mathrm{C} / \mathrm{kg} /$ day and $57.56 \mathrm{mg} \mathrm{C} / \mathrm{kg}$ soil in shifting cultivated land, respectively, and their corresponding values in mixed planted forest on an average were $1.70 \times 10^{5} \mathrm{cfu} \cdot \mathrm{g}^{-1}$ dry soil, $2.51 \times 10^{7} \mathrm{cfu} \cdot \mathrm{g}^{-1}$ dry soil, $6.02 \mathrm{CO}_{2}-\mathrm{C} / \mathrm{kg} /$ day and $71.70 \mathrm{mg} \mathrm{C} / \mathrm{kg}$ soil (Table 3).

Quotient of microbial respiration and organic carbon $\left(\mathrm{C}_{\text {Res. }} \mathrm{C}_{\mathrm{Org}}{ }^{-1}\right)$ as well as quotient of active microbial biomass and organic carbon $\left(\mathrm{C}_{\mathrm{AMB}} \mathrm{C}_{\mathrm{Org}}{ }^{-1}\right)$ were distinctly lower at 3 locations viz. Burburichara, Maichhari and Muralipara and higher at 2 shifting cultivated lands viz. Langadu and Sukurchhari than their compared adjacent mixed planted forest (Fig. 2, 3).

\section{Discussion}

\section{Soil physico-chemical properties}

Various reports (Miah et al. 2010; Biswas et al. 2010; Gafur et al. 2000) indicate that shifting cultivation may either decrease or increase soil $\mathrm{pH}$ depending on cultivation stage, runoff condition and amount of organic matter present on the land. Higher $\mathrm{pH}$ in shifting cultivated land at three locations namely Burburichara, Maichhari and Langadu was associated with addition of ashes in soil from complete burning of earlier vegetation before sowing paddy

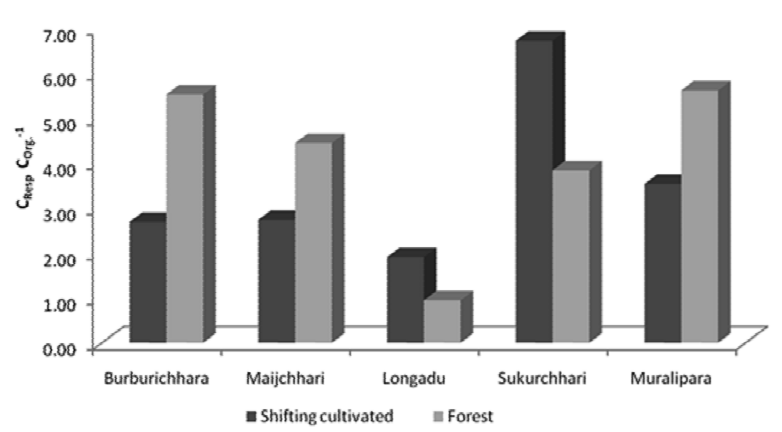

Fig. 2. Quotient of microbial respiration $\left(\mathrm{C}_{\text {Res. }}\right)$ and organic carbon $\left(\mathrm{C}_{\text {Org. }}\right)$ in soil of shifting cultivated and mixed planted forest lands in Rangamati district. seeds, turmeric and similar other crops and from deep hoeing of the soil. Moreover, these three locations also contained lower organic matter compared to adjacent mixed planted forest of several tree species having good canopy coverage. Biswas et al. (2010) also found in this mountainous region higher $\mathrm{pH}$ on land just after sowing at Alutila of Kharacharichari district. Gafur et al. (2000) reported higher $\mathrm{pH}$ from shifting cultivated area with more run-off compared to vegetated land comprised of mixed trees of horticulture and forest species in Soil Conservation and Watershed Management Center at Banderban. At Muralipara with the presence slashed materials as well as at Sukurchari with the presence of paddy residues of previous year showed lower $\mathrm{pH}$ compared to mixed tree plantation. The results therefore suggest that stage of shifting cultivation as well as site specific conditions influence the reaction of soil. Moreover, where now presence of tree vegetation previously this land also might pass through shifting cultivation, because with increased population in CHTs on each and every place either shifting cultivation or tree and fruit plantation in combination are being practiced. Similarly, lower $\mathrm{pH}$ in shifting cultivated land compared to village common forest/natural forest was reported by Miah et al. (2010) in mountainous region of Bandarban and Rangamati district.

Higher bulk density in the shifting cultivated land at all the locations was usually related with lower organic matter and compaction of soil. Sukurchari was an orchard dominated planted forest and Muralipara contained only one jackfruit tree representing a poor forest cover. For this reasons at these two sites organic matter content was lower and bulk density became higher compared to shifting cultivated

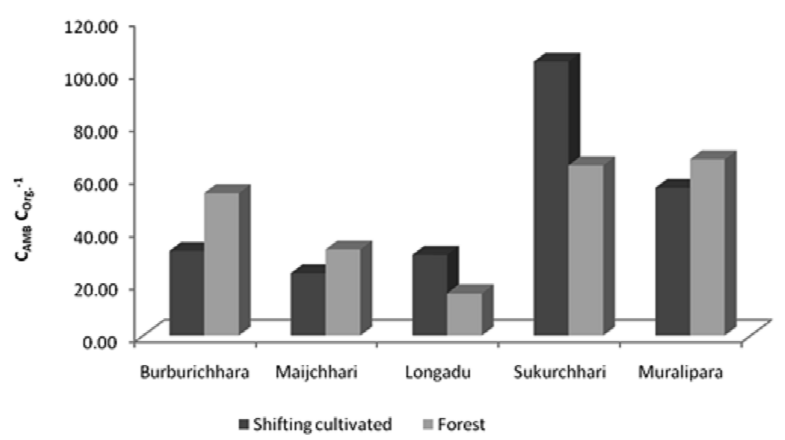

Fig. 3. Quotient of active microbial biomass $\left(\mathrm{C}_{\mathrm{AMB}}\right)$ and organic carbon $\left(\mathrm{C}_{\text {Org. }}\right)$ in soil of shifting cultivated and mixed planted forest lands in Rangamati district. 
land.

Lower total nitrogen in shifting cultivated soil was influenced by the absence of vegetation, burning of crop residues as well as accelerated soil erosion and reverse was true for forested land with the presence of more litter and tree coverage. Due to forest clearance lower total $\mathrm{N}$ content in soil was reported by several authors from different parts of the world (Girma 1998; Jing-cheng et al. 2004). DeBano et al. (1979) reported that losses of soil $\mathrm{N}$ can occur when heated to temperature as high as $100^{\circ} \mathrm{C}$, which may happen during burning associated with shifting cultivation. Significant increase in available $\mathrm{Ca}$ and $\mathrm{Mg}$ of the preset study compared to forest land in most of the locations was in agreement with Gafur et al. (2000), who also reported an increase of the two elements in shifting cultivated soil than mixed planted forest land in Banderban district.

It needs to mention here that land use in CHTs after 1990 is changing rapidly due to fast growing population and in absence of scope for rotation on the new available lands for cultivation. Thus many of the forests of the past time or shifting cultivated land are being brought under either shifting cultivation or fruit cultivation or tree and orchard in combination. However, all such lands in the long past was under natural forest with luxuriant growth. Thus, the three different locations viz. Maijchhari, Burburichhara and Longadu might past through only shifting cultivation, for which findings from the compared land showed rather better results.

\section{Soil biological population}

Shifting cultivation brought drastic changes of fungal as well as bacterial population, microbial respiration and active microbial biomass in soil because of several reasons. During shifting cultivation burning was done for land preparation which affected moisture content, organic matter and $\mathrm{pH}$ as well as vegetation coverage on soil. In extreme temperature from burning of soil associated with shifting cultivation, topsoil might undergo complete sterilization. Extreme high temperature affected survival and colonization of soil organisms through reduction and modification of organic substrates, reduction in sources of organic residues, buffering etc. (Bissett and Parkinson 1980; Monleon and Cromack 1996). Moreover, some organic pollutants were produced during combustion process which had also adverse effect on soil biota. Some toxic compounds, such as polychlorinated dibenzo- p-dioxins (PCDDs), dibenzofurans (PCDFs) and polynuclear aromatic hydrocarbons (PAHs) are released during fire and redistributed in soil (Kim et al. 2003). Islam and Weil (2000) reported that microbial communities in forest soils are more active and less stressed than any other land uses. Miah et al. (2010) also found higher fungi and bacterial population in village common forest compared to shifting cultivated soil in absence or with scattered vegetation in the same mountainous region in Banderban and Rangamati district. Lower microbial population in shifting cultivated land of the present study was supported by several researchers from outside countries also (Gupta et al. 1986; Islam and Weil 2000; Dthar and Mishra 1987). Dthar and Mishra (1987) reported that grass as well as forest lands had higher microbial population than shifting cultivated land. Thus, it is clear that absence of forests and burning in no way is beneficial to microbial population in soil.

Reduced active microbial biomass and basal respiration in shifting cultivated soil were related to lower microbial activity compared to mixed planted forest, which had significantly higher amount of moisture. Similarly reduced aggregate stability in shifting cultivated land was associated with lower input of labile $\mathrm{C}$ having lower amount of litter-fall and root exudates compared to either natural forest or plantation rich in litter and root exudates. Active microbial biomass is usually limited with the availability of labile $\mathrm{C}$ and sensitive to land-use type as well as soil management practices (Islam and Weil 2000). Dthar and Mishra (1987) found in shifting cultivated soil significant lower microbial population and biomass production compared to vegetated area, and a positive correlation revealed between bacterial population and moisture content in both the land uses. Microbial population and $\mathrm{CO}_{2}$ evolution are usually higher in the vegetated soils compared to that of 'slash and burn' type agriculture. A field experiment by Hedlund (2002) showed that the biomass of bacteria and fungi were higher in forest soil than in the adjacent agricultural land.

\section{Conclusion}

No doubt that shifting cultivation deteriorates soil environment through loss of vegetation and soil fertility, but this 
cultivation system cannot be stopped completely in $\mathrm{CHT}$, because this is the widely practiced primary occupation and major economic activities of the indigenous people in $\mathrm{CHTs}$ over the last several centuries. This cultivation system thus becomes the only source of sustenance for most ethnic backward people in this hilly region without the knowledge of modern cultivation. However, their indigenous knowledge in managing forest land is admirable, since they do minimum tillage for growing crops and manage community based forest sustainable way through community's prepared rules and regulations. With the settlement of plain land people and fast growth of their own families, this hilly region becomes over populated in comparison to cultivable land and has reduced the choice of shifting at present from one to other place as they did in the past. Thus lands are not getting any rest period to regain its fertility due to repeated cropping and people clear more forests for their livelihood. Under the circumstances the only option to increase permanent vegetated area through encouraging naturally regenerated hundreds of species which grow following monsoon rains in this only mountainous region of the country with the aim to stop deterioration of soil biological and physicochemical properties. To keep overall environment with respect to natural resources at optimum condition in this upland watershed shifting cultivation is to be restricted to only on gentle sloping land with the adoption of long cycle and creating alternative employment opportunities to the shifting cultivators for their livelihood at their door step through developing landscaping and tourism facilities in this mountainous region. However, to achieve such benefits and services in this distinct region from plain land geographically, culturally, demographically, economically, administratively, legally and historically, require political decision from all parties at local and national level with the assistance of international environmental associations.

\section{References}

Anderson TH, Domsch KH. 1990. Application of eco-physiological quotients $\left(\mathrm{qCO}_{2}\right.$ and $\mathrm{qD}$ ) on microbial biomasses from soils of different cropping histories. Soil Biol Biochem 22: 251-255.

Andreas HC, Petersen TR, Osman KO. 2007. Slash and burning in the Hill forest and its impacts. Dunarkti Press, Sharlwark, pp
11.

Ball DF. 1964. Loss-on-ignition as an estimate of organic matter and organic carbon in non-calcareous soils. J Soil Sci 15: 84-92.

Becker BK. 1995. Undoing Myths: The Amazon - An Urbanized Forest. In: Brazilian perspectives on sustainable development of the Amazon region (Clüsener-Godt $\mathrm{M}$, Sachs I, eds). UNESCO, Paris, pp 53-89.

Bissett J, Parkinson D. 1980. Long-term effects of fire on the composition and activity of the soil microflora of a sub alpine, coniferous forest. Canndian J Bot 58: 170-172.

Biswas S, Swanson ME, Shoaib JUM, Haque SMS. 2010. Soil chemical properties under modern and traditional farming systems at Khagrachari, Chittagong Hill Tracts, Bangladesh. J For Res 21: 451-456.

Blake GR. 1965. Bulk density. In: Methods of Soil Analysis - Part 1 Physical and Mineralogical Properties, Incl. Statistics of Measurement and Sampling (Black CA, Evans DD, White JL, eds). American Society of Agronomy, Madison, Wis, pp 374-390.

Clark FE. 1965. Agar-plate method for total microbial count. In: Methods of soil analysis. Part 2. Chemical and microbiological properties (Black CA, Evans DD, Ensminger LE, White JL, Clark FE, Dinauer RC, eds). American Society of Agronomy, Madison, Wis, pp 1460-1466.

DeBano LF, Eberlein GE, Dunn PH. 1979. Effects of burning on chaparral soils: I. Soil nitrogen. Soil Sci Soc Am J 43: 504-509.

Dodds WK, Banks MK, Clenan CS, Rice CW, Sotomayor D, Strauss EA, Yu W. 1996. Biological properties of soil and subsurface sediments under abandoned pasture and cropland. Soil Biol Biochem 28: 837-846.

Dthar MS, Mishra RR. 1987. Microbial population, fungal biomass and $\mathrm{CO}_{2}$ evolution in forest soil, India. Indian Forester 23: 253-259.

Dubey RC, Maheshwari DK. 1999. Text book of Microbiology. S. Chand \& Cmpany Ltd, New Delhi, pp 682.

Gafur A, Borggaard OK, Jensenc JR, Petersend L. 2000. Changes in soil nutrient content under shifting cultivation in the Chittagong Hill Tracts of Bangladesh. Geografisk TidsskriftDanish Journal of Geography 100: 37-46.

Girma T. 1998. Effect of cultivation on physical and chemical properties of a Vertisol in middle Awash Valley, Ethiopia. Commun Soil Sci Plant Anal 29: 587-598

Guppy N. 1984. Tropical deforestation : a global view. Foreign Affairs, New York, pp 62-65.

Gupta AK. 2000. Shifting cultivation and conservation of biological diversity in Tripura, Northeast India. Human Ecol 28: 605-629.

Gupta RD, Bhardwaj KR, Morwan BC, Tripathi BR. 1986. Occurrences of phosphate dissolving bacteria in soils of North Hymalatas under varying biosequence and climosequence. J Indian Soc Soil Sci 34: 498-504.

Hedlund K. 2002. Soil microbial community structure in relation 
to vegetation management on former agricultural land. Soil Biol Biochem 34: 1299-1307.

Huq SMI, Alam MDU. 2005. A Handbook on Analyses of Soil, Plant and Water. Dhaka: Bangladesh-Australia Center for Environmental Research (BACER-DU), pp 246.

Islam KR, Weil RR. 2000. Land use effects on soil quality in a tropical forest ecosystem of Bangladesh. Agriculture, Ecosystems \& Environment 79: 9-16.

Jackson 1973. Soil chemical analysis. Prentice-Hall Inc, New Jersey, pp 205-226.

Kim EJ, Oh JE, Chang YS. 2003. Effects of forest fire on the level and distribution of $\mathrm{PCDD} / \mathrm{Fs}$ and $\mathrm{PAHs}$ in soil. Sci Total Environ 311: 177-189.

Miah S, Dey S, Haque SMS. 2010. Shifting cultivation effects on soil fungi and bacterial population in Chittagong Hill Tracts, Bangladesh. J For Res 21: 311-318.

Monleon VJ, Cromack K jnr. 1996. Long-term effects of prescribed underburning on litter decomposition and nutrient release in ponderosa pine stands in central Oregon. For Ecol Manage 81: 143-152.

Petersen L. 2002. Analytical methods of soil, water, pant material and fertilizer. Soil resources management and analytical services. Kampsax: Soil resource development institute Danida.

Philon WJ. 1998. Effects of shifting cultivation in forest and causes losses of soil organic matter. Physicong Press, Philippines, pp 23.

Postel S, Heise L. 1998. Reforesting the earth. Worldwatch Institute, Washington, D.C.
Sandra P, Lori H. 1988. Reforestation the Earth. World Watch paper 83, 4/88. Sfeir-Younis and Dragun.

Sandra P. 1984. Protecting Forest. in India Strake, (ed.) State of the World 1984. W. W. Norton and Co, New York, pp 74-94.

Seubert CE. 1975. Effects of land clearing methods on crop performance and changes in soil properties in an Ultisol of the Amazon Jungle of Peru. University at Raleigh, pp 152.

Sommer R Vlek PLG, de Abreu Sá TD, Vielhauer K, Coelho RFR, Fölster H. 2004. Nutrient balance of shifting cultivation by burning or mulching in the Eastern Amazon - evidence for subsoil nutrient accumulation. Nutr Cycl Agroecosys 68: 257-271.

Suhrawardy BH. 1995. Outline of the Chittagong economy: An analysis (in Bengali). In: Tripura A. et al. (eds.), Vision Rangamati. Rangamati. Bangladesh, pp 33-38.

Tripura P, Harun A. 2003. Crisis and Struggle of Shifting Cultivator in the CHTs. Dhaka: Women Volunteers Association, June 12-13, pp 1-7.

Van De Werf H, Verstraete W. 1987. Estimation of active soil microbial biomass by mathematical analysis of respiration curves: Relation to conventional estimation of total biomass. Soil Biol Biochem 19: 267-271.

Wikipedia. 2009. http://en.wikipedia.org/wiki/Chittagong_Hill_ Tracts\#Demography. Accessed on 3 Apr 2009.

Yang JC, Huang JH, Pan QM, Tang JW, Han XG. 2004. Long-term impacts of land-use change on dynamics of tropical soil carbon and nitrogen pools. J Environ Sci (China) 16: 256-261. 